\title{
Economic Crisis, Poor Governance and the Rise of Populism: The Case of Greece
}

The eurozone crisis has become associated with the rise of populism across Europe as it has coincided with increasing electoral support for political actors who seek to return politics back to 'the people'. This has taken place in different forms, depending on whether the country was a debtor or creditor, the salience of cultural and/or economic cleavages and other contextual factors.

\section{Right-wing and left-wing populism in Europe}

In most instances, particularly in Western Europe, the populist actors that enjoyed increasing electoral support came from the right of the political spectrum. These are parties that define the people on the basis of an ingroup/out-group dimension, and emphasise the need to 'take back control' and restore national sovereignty. They identify the people with the in-group and suggest that this group should be exclusively granted access to the collective goods of the state. As such, the signature theme of right-wing populists is limiting immigration. Examples abound: the French Rassemblement National (RN - formerly Front National), the Dutch Party for Freedom (PVV), the Swiss People's Party (SVP), the Alternative for Germany (AfD), the Sweden Democrats (SD) and the Danish People's Party (DF) have all fared well electorally in their respective arenas. What these parties have in common beyond their immigration skepticism is their conscious effort to distance themselves from the violence, fascism and extremism that defined the far right in the past in order to broaden their electoral appeal.

Less frequently, and predominantly in Southern Europe where economic cleavages remain salient, successful populist forces have originated from the left of the political spectrum. Left-wing populism defines the people on the basis of a have and have-not dimension and emphasises equality and redistribution. A good example is the Spanish party Podemos.

Greece is in many ways an exceptional case because, subsequent to the eruption of the economic crisis, it experienced the rise of both types of populism. During the May

Daphne Halikiopoulou, University of Reading, UK. and June 2012 elections, small anti-establishment parties from both sides of the political spectrum increased their electoral support, including the extreme right Golden Dawn, the radical right Independent Greeks (Anel) and the Coalition of the Radical Left (Syriza). Greece also diverges from Western European patterns with regards to the Golden Dawn's extremism and violence, which contrary to other far right actors in Europe increased its representation because of, and not despite, its extremism.

This article focuses on the Greek case, in an attempt to shed light on its exceptionalism. Its aim is threefold. First, to present a brief theoretical discussion of populism and place Greece within this framework; second, to focus on the rise of the Golden Dawn, which is one of the few European - and the only Western European - extreme rightwing parties to enjoy parliamentary representation; and third, to place this phenomenon within an explanatory framework that extends beyond the economic crisis to the role of state institutions and governance.

\section{Defining populism}

Most definitions of populism centre on its emphasis on the people and its attempt to mobilise the 'masses' against a purported enemy by drawing on a dichotomy between the 'pure people' and the 'corrupt elite'.' While the focus on the people is a descriptor of populist parties, it does not necessarily tell us something analytical about populism. After all, who in a democracy does not speak about the people, to the people and on behalf of the people to some extent? What is also important about populism is the extent to which it places the people at the heart of collective decision-making. ${ }^{2}$

According to populists, collective decisions must be made from below: only decisions made by 'the people'

(C) The Author(s) 2020. Open Access: This article is distributed under the terms of the Creative Commons Attribution 4.0 International License (https://creativecommons.org/licenses/by/4.0/).

Open Access funding provided by ZBW - Leibniz Information Centre for Economics.

1 C. Mudde: Populist Radical Right Parties in Europe, New York 2017, Cambridge University Press; P. Taggart: Populism, Buckingham 2000, Open University Press.

2 W. Riker: Liberalism against Populism: A Confrontation between the Theory of Democracy and the Theory of Social Choice, Illinois 1982, Waveland Press. 
are legitimate and morally superior. In other words, the key feature of populism is that it seeks to bypass representative institutions in the name of the 'popular will'. ${ }^{3}$ The implications are paramount: beyond just the communication style, ideology or strategy that parties adopt, it is a system of governance - an alternative vision of democratic society that such parties seek to implement. ${ }^{4}$ This vision downplays institutions and idealises the 'will of the people', which it portrays as an indivisible entity, ${ }^{5}$ failing to acknowledge the existence of different social groups and the need for reconciliation of their often clashing preferences. ${ }^{6}$

In sum, populism is a form of politics because ultimately it puts forward a vision about how societies should be making, legitimating and implementing collective choices. ${ }^{7}$ Populism has the following characteristics:

- a flamboyant rhetoric that often seeks to attribute blame to those not identified as 'the people'

- the portrayal of the people as an indivisible entity

- adversarial politics and polarisation

- a hostility towards liberal democracy and the institutions that secure its procedures; and hence

- a propensity towards authoritarianism.

\section{Populism in Greece}

Whereas across Western Europe, the salience of an emerging cultural cleavage has triggered the rise of rightwing populist parties that focus on immigration, in Greece the salience of the materialist cleavage exacerbated by the country's severe and protracted economic crisis gave rise to populist forces of both the right and the left. The Greek economic crisis of 2009 was soon followed by a political crisis, as the country's two-party system that had dominated Greek politics since the restoration of democracy in 1974 imploded. The post-crisis elections were characterised by the near collapse of the centre-left Panhellenic Socialist Movement (Pasok), which voters associated directly with the crisis. Support for the party dropped from $43.9 \%$ in 2009 to $12.3 \%$ in June 2012 and

3 M. Freeden: After the Brexit referendum: revisiting populism as an ideology, in: Journal of Political Ideologies, Vol. 22, No. 1, 2017, pp. 1-11; D. Halikiopoulou: Right-wing Populism as a Nationalist Vision of Legitimating Collective Choice: A Supply-side Perspective, in: The International Spectator, Vol. 54, No. 2, 2019, pp. 35-49; B. Bonikowski, D. Halikiopoulou, E. Kaufmann, M. Rooduijn: Populism and nationalism in a comparative perspective: a scholarly exchange, in: Nations and Nationalism, Vol. 25, No. 1, 2019, pp. 5881.

4 W. Riker, op. cit.

5 M. Freeden, op. cit.

6 D. Halikiopoulou, op. cit.

7 B. Bonikowski, D. Halikiopoulou, E. Kaufmann, M. Rooduijn, op. cit.
4.7\% in January 2015. Centre-right New Democracy (ND), which has been in power alternately with Pasok for the past 40 years also declined because of its association with austerity and harsh economic measures.

In January 2015, Greece elected a government with a clear anti-austerity mandate, consisting of a radical leftradical right coalition between Syriza and Anel. ND came second with just over $27.8 \%$ of the vote. The result was a landslide for Syriza, which attracted broad support from voters who punished mainstream parties - especially Pasok - for their failure to manage the effects of the crisis. Support for the party soared from $4.6 \%$ in 2009 to $26.9 \%$ in June 2012, and $36.3 \%$ in 2015 . Syriza won the election on a left-wing populist narrative that attributed blame to outside exploitative powers and their collaborators and sought to restore sovereignty back to the Greek people. Anel, an offshoot of ND, received $4.8 \%$ of the vote by also campaigning on a populist platform.

Indeed, while unlikely bedfellows for many, Syriza and Anel shared a populist narrative based on their anti-austerity stance. Their rise is indicative of the rise of a type of populism in Greece that was adopted by most parties in the system in an attempt to divert political accountability through populist blame-shifting. ${ }^{8}$ While left- and rightwing populist parties were divided on key social issues, including religion and immigration - for example, the Macedonian question, Cyprus, and Greece's relationship with Turkey - they still shared a nationalist rhetoric of liberation, restoration of national sovereignty, a strong rejection of external involvement and resistance to foreign domination. ${ }^{9}$

In sum, the type of populism that emerged in Greece as a response to the economic crisis has four key features:

1. It was expressed through the narratives of all political actors;

2. Therefore, it was observed across the party system;

3. It was expressed in the forms of blame-shifting and exclusivity; and

4. It differed depending on ideology and position in the party system. ${ }^{10}$

8 S. Vasilopoulou, D. Halikiopoulou, T. Exadaktylos: Greece in crisis: Austerity, Populism and the Politics of Blame, in: Journal of Common Market Studies, Vol. 52, No. 2, 2014, pp. 388-402.

9 D. Halikiopoulou, S. Vasilopoulou: Greece's response to austerity has been to say "no to the Fourth Reich" but yes to the neo-Nazism of the Golden Dawn, LSE EUROPP Blog, 2012, available at https://blogs.Ise.ac.uk/europpblog/2012/10/15/greece-golden-dawn/.

10 S. Vasilopoulou, D. Halikiopoulou, T. Exadaktylos, op. cit. 


\section{The Golden Dawn: Extreme right-wing populism?}

What is also distinct about Greece is the rise of the Golden Dawn, an extremist, violent, ultra-nationalist and openly neo-Nazi party which progressed from limited membership of extreme right-wing activists, predominantly street activities and very low levels of electoral support in the 1990s and early 2000s to capturing just under 7\% in 2015 (Table 1).

This rise of the Golden Dawn contradicts the Europeanwide pattern of far right populism. In most European countries, the most successful radical right-wing parties are those that have sought to disassociate themselves from extremism such as the French RN, the Dutch PVV, the Swiss SVP, the German AfD and the Scandinavian $\mathrm{SD}$ and DF. These parties share a common narrative that emphasises ideological rather than biological criteria of national belonging, adopting a seemingly more inclusive form of nationalism ${ }^{11}$ and distancing themselves from fascism. ${ }^{12}$

Furthermore, the Golden Dawn is not only openly violent and racist, but for most of the post-crisis period its leading cadres have been standing trial for charges including maintaining a criminal organisation, murder and grievous bodily harm. While it might be argued that extremist parties such as the Golden Dawn cannot be classified as populist, I argue that in fact what characterises the party's rhetoric is a clear merger of populism and nationalism. This is because of:

- Its emphasis on the legitimacy of politics carried out from below, which is a key feature of populism as discussed above; and

- The adoption of a 'palingenetic myth' of populist ultranationalism that allows the party to present itself as the saviour of the Greek nation and defender of the national mission. ${ }^{13}$

Specifically, while the party rejects the 'fascist label', it actually espouses all core fascist principles in its supplyside materials. This entails an endorsement of politics from below. For example, the Golden Dawn presents its leader not as the representative but as the embodiment

11 D. Halikiopoulou, S. Mock, S. Vasilopoulou: The civic zeitgeist: nationalism and liberal values in the European radical right, in: Nations and Nationalism, Vol. 19, No. 1, 2013, pp. 107-127.

$12 \mathrm{M}$. Golder: Explaining Variation in the Success of Extreme Right Parties in Western Europe, in: Comparative Political Studies, Vol. 36, No. 4, 2003, pp. 432-466.

13 S. Vasilopoulou, D. Halikiopoulou: The Golden Dawn's nationalist Solution: Explaining the Rise of the Far Right in Greece, New York 2015, Palgrave.
Table 1

\section{Election results of the Golden Dawn}

\begin{tabular}{llcc} 
Year & Election type & Percentage & Seats \\
\hline 1994 & EP & 0.11 & 0 \\
\hline 1996 & National & 0.07 & 0 \\
\hline 2009 & EP & 0.46 & 0 \\
\hline 2009 & National & 0.29 & 0 \\
\hline May 2012 & National & 6.97 & 21 \\
\hline June 2012 & National & 6.92 & 18 \\
\hline 2014 & EP & 9.39 & 3 \\
\hline January 2015 & National & 6.28 & 17 \\
\hline Sepember 2015 & National & 6.99 & 18 \\
\hline 2019 & EP & 4.87 & 2 \\
\hline 2019 & National & 2.93 & 0 \\
\hline
\end{tabular}

So urce: Greek Ministry of Interior, www.ypes.gr.

of the Greek people and their collective will. In addition, the Golden Dawn espouses the 'third biggest ideology in history', i.e. nationalism and supports the establishment of the state in accordance with this principle, placing an extensive emphasis on the Nation (which it refers to with capital ' $N$ '). By employing the twin fascism myths of social decadence and national rebirth, the Golden Dawn promised disillusioned Greek voters a nationalist solution to all their socio-economic problems. ${ }^{14}$ It has done so through a narrative that presents Europe as a problem of national exploitation and draws heavily on Greek history, the distinction between superior and inferior nations, the strong sense of Greek ethnic superiority and the portrayal of the Greek nation under threat.

\section{The comparative dimension: Poor governance}

How is it possible that a country which prides itself on having resisted fascism and authoritarianism during WWII and the junta years (1967-1973), became one of the few European cases with an openly neo-Nazi party in parliament? Extensive work carried out on Golden Dawn voting patterns and supply-side materials suggests that the economic crisis alone is insufficient in explaining this outcome. $^{15}$

A brief comparative examination illustrates why other Southern European countries, with a similar history of

\footnotetext{
14 Ibid.

15 Ibid.; D. Halikiopoulou, S. Vasilopoulou: Breaching the social contract: crises of democratic representation and patterns of extreme right party support, in: Government and Opposition, Vol. 53, No. 1, 2018, pp. 26-50.
} 
authoritarianism and comparable indicators of economic malaise such as unemployment and declining GDP, did not experience a similar phenomenon. This includes Spain, whose crisis coincided with the populist left Podemos, and later the populist right Vox - which however does not compare to the Golden Dawn in terms of its espousal of fascism and violence; and Portugal, which despite a severe economic predicament did not experience a populism wave.

What differs between these cases is the nature rather than the intensity of the crisis. ${ }^{16}$ The economic crisis in Greece - as opposed to that in Spain and Portugal - ultimately culminated in a crisis of democracy and political representation as Greek citizens perceived the state as unable to mitigate the recession. This may be attributed to the weakness of the country's institutions and the deeply entrenched clientelistic networks that permeated all aspects of social and political life in Greece since the restoration of democracy. This system may have facilitated some development during times of international financial stability, but also meant that the country was unable to withstand external shocks. ${ }^{17}$ Severe issues of governability resulting from these arrangements significantly impacted the ability of the state to fulfil its obligations to citizens and were accompanied by declining levels of trust in state institutions, resulting in a party system collapse..$^{18}$

This suggests that the rise of the Golden Dawn is closely related to the breakdown of political trust, good governance and the perceived efficacy of the state. Ultimately, Golden Dawn's success needs to be understood as dependent upon the extent to which it was able to propose plausible solutions to the three sets of crises - economic, political and ideological - that befell Greece and culminated in an overall crisis of democracy. ${ }^{19}$

\section{How resilient is Greece's populism?}

According to many analysts and commentators, the July 2019 elections in Greece marked 'a return to normality'20

16 Previously stated in ibid.

17 M. Mitsopoulos, T. Pelagidis: Understanding the Crisis in Greece: From Boom to Bust, Basingstoke 2011, Palgrave Macmillan; T. Pappas: Why Greece Failed, in: Journal of Democracy, Vol. 24, No. 2, 2013, pp. 31-45; S. Vasilopoulou, D. Halikiopoulou, T. Exadaktylos, op. cit.

18 D. Halikiopoulou, S. Vasilopoulou:: Breaching the social contract..., op. cit.

19 S. Vasilopoulou, D. Halikiopoulou, 2015, op. cit.

$20 \mathrm{H}$. Mylonas: After a decade of crisis, Greek politics are turning normal and more technocratic', Washington Post, 14th July 2019. and 'first defeat of populism in Europe'. ${ }^{21}$ The populist left Syriza lost the election to the centre-right New Democracy party, which won with $39.85 \%$ of the popular vote and 158 seats from a total of 300 . The Golden Dawn received $2.93 \%$, failing to pass the $3 \%$ threshold, exiting the Greek parliament after seven years. The result of this election may be understood as an illustration of the need for stability, as the Greek electorate opted for a technocratic, as opposed to openly populist, government, deemed efficient to handle the economy.

However, such analyses may be premature and should be treated with caution. Greece's illiberal democracy defined by adversarial politics, the adoption of populist narratives across the party system and weak democratic institutions governed by rent-seeking behaviour - poses significant constraints on the possibility for successful reform. ${ }^{22}$ A brief look at the country's political scene since July 2019 illustrates this empirically. First, while the Golden Dawn exited parliament, other populist forces still enjoy parliamentary representation, for example the populist right Greek Solution (ten seats) and the populist left MeRa25 (nine seats). Second, the development of the protracted Golden Dawn trial shows signs of reluctance to attribute significant criminal activity to the party and its leading cadres. Third, there are already signs of increasing discontent as New Democracy initiatives become linked to increasing conservatism - for example with regards to the role of the church, abortion and other social issues.

All this suggests that underlying systemic problems in Greece persist and pose a test for the current and any subsequent governments facing a similar constraint: how to implement structural reforms while not compromising their own position in the status quo by alienating large sections of the population who have benefited structurally from the existing system. This ultimately can only be done through the establishment of resilient democratic institutions that can offer effective checks and balances and counter-populism on a structural level. Without these, populism remains a likely destabilising force. 